\title{
An Imported Measles Outbreak in Al Buraimi Governorate, Oman, in April 2020
}

\author{
Hanan Al-Marbouai, BSc, MD \\ Directorate of Disease Surveillance and Control, Directorate General of Health Services, Ministry of Health, Al-Buraimi, Oman
}

\section{Corresponding Author:}

Hanan Al-Marbouai, BSc, MD

Directorate of Disease Surveillance and Control

Directorate General of Health Services

Ministry of Health

Al-Buraimi, 154

Oman

Phone: 96896554959

Fax: 96825657147

Email: hananh19@hotmail.com

\section{Abstract}

Background: On April 16, 2020, the communicable disease department of Al Buraimi Governorate, Oman, was notified about 3 cases of measles. On laboratory confirmation of measles on April 19, 2020, further field investigation was conducted. Oman has had few cases of measles since 1995; however, Al Buraimi Governorate has had imported cases of measles in recent years.

Objective: We conducted this study to investigate the epidemiology of imported cases of measles in Al Buraimi, Oman, in April 2020.

Methods: This case series retrospectively reported measles cases. Epidemiological investigation began by meeting the families of the affected children. The data obtained included clinical symptoms, exposure information, travel history, immunization, and history of contact with others.

Results: Among the positive cases of measles, $75 \%$ were in girls and $25 \%$ were in boys. In addition, 6 patients were Afghani nationals and 2 were Pakistani nationals. A detailed investigation that included virus isolation and genotyping identified the B3 genotype in all measles cases and traced the virus to Pakistan as the country of origin. Despite Pakistan being the place of origin of the virus, most cases of measles (75\%) were reported in Afghani nationals because of low vaccination coverage. We also found that most of the children affected were 10 to 19 years old $(75 \%)$. All children who did not have vaccination records or were unvaccinated, regardless of whether they had contracted the virus, were given the measles-mumps-rubella vaccine. This was done to prevent future outbreaks and to increase measles vaccination coverage.

Conclusions: This study demonstrated that the greatest challenge in eliminating measles in Oman is imported cases among non-Omani expatriates and unvaccinated children. It should therefore be a priority to vaccinate all expatriate children. Only when everyone is vaccinated in Oman can the goal of creating a measles-free country be realized.

(iproc 2022;8(1):e36683) doi: $10.2196 / 36683$

\section{KEYWORDS}

imported measles; Al Buraimi; Oman; children; Afghanistan; Pakistan; vaccinated; unvaccinated 
Edited by Y Khader; this is a non-peer-reviewed article. Submitted 20.01.22; accepted 24.01.22; published 10.02.22.

Please cite as:

Al-Marbouai $H$

An Imported Measles Outbreak in Al Buraimi Governorate, Oman, in April 2020

iproc 2022;8(1):e36683

URL: https://www.iproc.org/2022/1/e36683

doi: $\underline{10.2196 / 36683}$

PMID:

(CHanan Al-Marbouai. Originally published in Iproceedings (https://www.iproc.org), 10.02.2022. This is an open-access article distributed under the terms of the Creative Commons Attribution License (https://creativecommons.org/licenses/by/4.0/), which permits unrestricted use, distribution, and reproduction in any medium, provided the original work, first published in Iproceedings, is properly cited. The complete bibliographic information, a link to the original publication on https://www.iproc.org/, as well as this copyright and license information must be included. 